\title{
Transitioning from conventional continuous grazing to planned rest-rotation grazing: A beef cattle case study from central Texas
}

\author{
R.D. Harmel, D.R. Smith, R.L. Haney, J. Angerer, N. Haile, L. Grote, S. Grote, K. Tiner, J. Goodwin, \\ R. Teague, and J. Derner
}

\begin{abstract}
Debate on the superiority of rotational or continuous grazing continues, but proponents of each call for additional research to enhance grazing management decisions. The short-term impact of transitioning from continuous grazing to an alternative grazing system is not well understood even though the transition can require substantial changes in infrastructure and management decisions related to forage availability, grazing duration and livestock movement, forage planting, and supplemental feeding. The objective of this five-year case study in a humid, subtropical environment was to evaluate real-world challenges and opportunities for beef cattle operations transitioning from conventional continuous grazing to a planned rest-rotation grazing system. The experimental data and observations (i.e., forage production, diet quality, cattle response, economics, and soil health) showcased that management changes under the planned rest-rotation system had potential for increased annual forage production, improved soil health (on cultivated grazed paddocks with multispecies forage crops, but not on grassland), and reduced costs; however, conventional continuous grazing produced higher body condition scores for cows and higher revenue. Average annual profits ( US $\$ 5.32 \mathrm{ac}^{-1}$ [US $\$ 2.15 \mathrm{ha}^{-1}$ ]) were similar for both grazing systems considering all economic factors. Key lessons learned and challenges faced include the difficulty of no-till establishment of cool-season multispecies forage in cultivated grazed paddocks and the importance of adequate fertilization of supplemental forage crops and dietary supplementation in the cold season.
\end{abstract}

Key words: cover crops_-economics—-grazing systems—rotational grazing—soil health

\begin{abstract}
Grazing lands are complex socio-ecological systems that provide vegetation for livestock consumption and a host of other ecosystem services including clean water, recreation, and wildlife habitat (Havstad et al. 2007; Gunter and Cole 2016). Grazing management occurs along a continuum of alternative strategies (Kachergis et al. 2013; Roche et al. 2015a). Grazing managers often adjust the timing and intensity of grazing, length of graze and rest periods, and livestock distribution to achieve production and environmental goals (Toombs et al. 2010; Teague et al. 2013). Adaptive management that achieves ecosystem health and profitability goals typically involves a basic
\end{abstract}

understanding of rangeland dynamics, consideration of diverse constraints including spatial and temporal variability, and determination of appropriate short- and long-term indicators and responses (Teague et al. 2011; Derner et al. 2021). The influence and complexity of human dimensions are critical factors for adaptive management (Briske et al. 2011b; Roche et al. 2015b; Derner and Augustine 2016; Wilmer et al. 2018a, 2018b).

Several adaptive management strategies can be used in humid subtropical regions (e.g., central Texas) in attempts to increase vegetation and livestock production. For example, overseeding grassland with cool-season species and incorporating annual

Received September 16, 2020; Revised February 17, 2021; Accepted March 11, 2021; Published online August 20, 2021. crops and forages increases forage production and diversity (Rouquette Jr. 2017). Resulting increased plant cover reduces soil erosion and improves soil health through increased organic carbon (C) and microbial diversity (Franzluebbers 2007; Toombs et al. 2010; Delgado et al. 2011). Cover crops and organic soil amendments (e.g., manure) can reduce inorganic fertilizer use, and conversion of marginal and/or degraded cropland to grassland can improve soil structure, fertility, and health, and reduce soil erosion (Franzluebbers 2007; Delgado et al. 2011). Additionally, managing for adequate standing hay (dry matter) entering the dormant season can reduce the need for supplemental feed or hay, though additional protein and energy may be required if forage quality is poor during this period.

Rotational grazing is another such alternative management strategy that has been vigorously debated in recent decades; specifically, is rotational grazing a superior strategy versus continuous grazing (Briske et al. 2008)? Rotational grazing is defined as the movement of livestock between paddocks to provide alternating periods of grazing and rest (Heitschmidt and Taylor 1991). Multipaddock grazing strategies emphasize short (days to weeks) grazing periods followed by longer (months to over a year) rest and recovery periods (Roche et al. 2015a). Benefits of rotational grazing have been reported in more mesic, productive environments (Gerrish 2004; Jacobo et al. 2006; Delgado et al. 2011; Janzen 2011; Teague et

R. Daren Harmel is the director of the USDA Agricultural Research Service (ARS) Center for Agricultural Resources Research (CARR), Fort Collins, Colorado. Douglas R. Smith is a soil scientist and research leader of the Grassland Soil and Water Research Laboratory, Temple, Texas. Rick L. Haney is a soil scientist at the Grassland Soil and Water Research Laboratory, Temple, Texas. Jay Angerer is range scientist and research leader of the Livestock and Range Research Laboratory, Miles City, Montana. Nathan Haile is a zone agronomist, USDA Natural Resources Conservation Service (NRCS), Victoria, Texas. Lynn Grote, Steve Grote, and Kyle Tiner are technicians at the USDA ARS Riesel Watersheds, Riesel, Texas. Jeff Goodwin is a range scientist at the Noble Research Institute, Ardmore, Oklahoma. Richard Teague is a professor and associate resident director of the Texas Agrilife Research and Extension Center, Vernon, Texas. Justin Derner is a range scientist and research leader at the USDA ARS-CARR, Fort Collins, Colorado. 
al. 2011, 2013; Jakoby et al. 2015), but definitive results are lacking in arid and semiarid conditions (Briske et al. 2008).

Rotational grazing employs adaptive management within multipaddock infrastructure attempting to (1) more properly match forage demand with forage availability, (2) provide user-defined postgrazing residual forage amounts, (3) facilitate temporal changes in length of vegetation recovery (i.e., rest from grazing) as environmental conditions change, and (4) reduce inputs (Gerrish 2004; Butterfield et al. 2006; Teague et al. 2013). Rotational grazing advocates typically point to the potential for increased stocking rates resulting from increased forage production and better forage harvest efficiency, and they acknowledge the additional costs (e.g., fences, water [Windh et al. 2019]) and management intensity required (Knight et al. 2011).

Briske et al. (2011a) and Teague et al. (2013) provide thorough background information on rotational and continuous grazing, and while many of their conclusions differ, both agree on the critical importance of additional considerations (e.g., complexity of the grazing systems, human dimensions, adaptive management, and direct onsite versus ecosystem benefits). Both have similar objectives - to maintain or restore ecosystem function and to increase ranch sustainability and profitability - but address causal mechanisms and biological drivers differently.

Based on the need for additional experimentation to provide valid science on alternative grazing systems, which is advocated for by both camps (Briske et al. 2011a; Teague et al. 2011), we implemented a case study in central Texas on a showcase ranchlevel beef cattle operation under humid subtropical conditions. The study was designed to evaluate the short-term impacts of transitioning from a continuous grazing system to management-intensive planned rest-rotation system. Are there important "lessons learned" that occur in this transition phase that have largely been ignored in the literature to date? We also wanted to capture the complexities of beef production enterprises and the rationale for grazing management decisions to maximize earnings in the short term at the expense of long-term productivity and resource capital value (well described by Rolfe et al. [2016]; Teague et al. [2019b, 2020]) that research and extension programs often fail to fully appreciate. The experimental data and observations (i.e., for- age production, diet quality, cattle response, economics, and soil health) showcase realworld challenges and opportunities.

\section{Materials and Methods}

Site Description. This study was conducted at the USDA Agricultural Research Service (ARS) Grassland Soil and Water Research Laboratory "Riesel Watersheds" near Riesel, Texas (figure 1). The Riesel Watersheds are a Historic Landmark of Agricultural and Biological Engineering and a Long-Term Agroecosystem Research (LTAR) network site. Located in the Texas Blackland Prairies ecoregion (Omernik 1987), soils are dominated by highly expansive Vertisols (shrink-swell clay soils), particularly the
Houston Black clay soil (fine, smectitic, thermic, udic Haplustert, 17\% sand, 28\% silt, and $55 \%$ clay). These soils are very slowly permeable when wet (saturated hydraulic

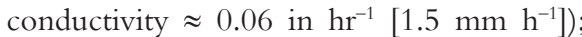
however, preferential flow associated with soil cracks contributes to high infiltration rates when the soil is dry (Arnold et al. 2005; Allen et al. 2005). This ecoregion is characterized by gently rolling terrain, fertile prairie soils, and a sub-humid climate. Grasslands are predominantly introduced Bermuda grass (Cynodon dactylon) and native rangeland used for grazing and hay production.

Implementation of the Case Study Design. In 2011, we initiated planning and conducted a resource inventory based on USDA Natural

\section{Figure 1}

Land use for the North Ranch with a "planned rest-rotation" grazing system and the South Ranch with a "conventional" grazing system.

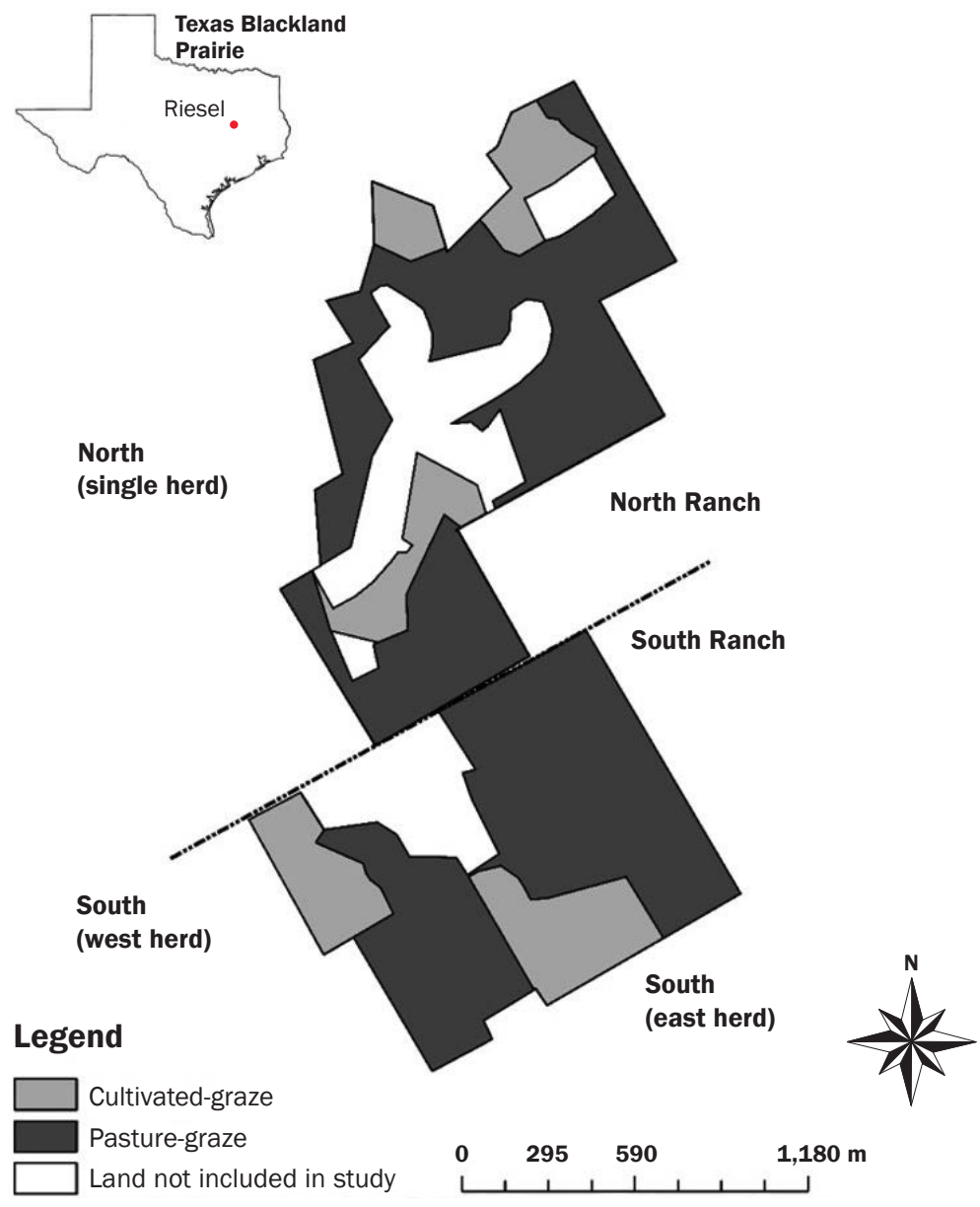


Resources Conservation Service (NRCS) guidance (USDA NRCS 2003, 2013). In January of 2012, the 563 ac (228 ha) ranch was divided into two similar smaller ranches.

The South Ranch was randomly assigned the conventional treatment with year-long continuous grazing on 282 ac (114 ha; three cultivated grazed paddocks: 71 ac [29 ha]; nine grassland paddocks: $211 \mathrm{ac}$ [85 ha]; figure 1). This ranch was managed like a majority of working ranches in Texas that utilize conventional continuous grazing. Each paddock on the South Ranch, whether grassland or cultivated with forage oats (Avena sativa L.) planted, was grazed and/or hayed, and stocking rate was held fairly constant regardless of forage conditions. Additional "business as usual" practices on this ranch included (1) moderate to heavy stocking rates, (2) reliance on hay during the dormant season to supplement grazing on cultivated oats, (3) separate herds, (4) "best pasture" grazing in which all gates were open and cattle in each herd were allowed to access all grassland paddocks on that side of the east/west divide, and (5) conventional inorganic fertility and herbicide management. Detailed management information for the continuous grazing system appears in tables 1 and 2 .

The North Ranch was randomly assigned the "planned rest-rotation" grazing system on 281 ac (114 ha; three cultivated grazed paddocks: 61 ac [25 ha]; nine grassland paddocks: 220 ac [89 ha]; figure 1). On the North Ranch, we incorporated historical knowledge and considered NRCS recommendations and made adaptive management decisions based on the following objectives: maintain short-term profits, reduce input costs, and increase long-term production and profitability. Each paddock, whether grassland or cultivated with mixed-species forage crops planted, was rotationally grazed with stocking rate and paddock subdelineation adjusted for forage conditions. Under this "aspirational" planned rest-rotation grazing strategy, we (1) created a single herd to produce short-term high stocking densities, (2) grazed grassland paddocks on a planned rotation based on moderate ( $50 \%)$ utilization to allow sufficient time for full plant recovery before regrazing, (3) overseeded selected grassland paddocks with cool-season multispecies forage crops, (4) planted warmand cool-season multispecies forage crops on cultivated grazed paddocks with periodic organic fertilizer application, (5) left standing forage to decrease supplemental feeding of hay in the dormant season, (6) used no-till planting to reduce soil disturbance, and (7) decreased inorganic fertilizer use. Detailed management information for the planned rest-rotation grazing system appears in tables 2 and 3.

Hydrology, Erosion, and Weather. Hydrologic, soil erosion, and weather data

\section{Table 1}

Land management for grassland and cultivated grazed paddocks on the South Ranch under the conventional continuous grazing system.

\begin{tabular}{|c|c|c|c|c|c|c|c|c|c|}
\hline Paddock & $\begin{array}{l}\text { Area } \\
\text { (ha) }\end{array}$ & $\begin{array}{l}\text { Area } \\
\text { (ac) }\end{array}$ & $\begin{array}{l}\text { Dominant } \\
\text { vegetation }\end{array}$ & $\begin{array}{l}\text { Recent } \\
\text { management }\end{array}$ & 2012 & 2013 & 2014 & 2015 & 2016 \\
\hline $9-21$ & 1.9 & 4.6 & Native* & Hay & Graze & Graze & Graze & Graze & Graze \\
\hline W10 & 17.6 & 43.6 & $\begin{array}{l}\text { Coastal } \\
\text { Bermuda }\end{array}$ & $\begin{array}{l}\text { Poultry litter } \\
2001-07, \\
\text { hay, grazed }\end{array}$ & Graze & Graze & Graze & Graze & Graze \\
\hline $7-5,7-6$ & 20.2 & 49.8 & Coastal Bermuda & $\begin{array}{l}\text { Hay, graze; } \\
\text { plowed } \\
\text { (leveled) }\end{array}$ & $\begin{array}{l}\text { Winter forage, } \\
\text { graze, hay, } \\
\text { poultry litter }\end{array}$ & $\begin{array}{l}\text { Winter forage, } \\
\text { graze, hay, }\end{array}$ & Graze & Graze & Graze \\
\hline $7-10$ & 23.6 & 58.2 & Native & Graze & Graze & Graze & Graze & Graze & Graze \\
\hline $20 x$ & 3.2 & 7.9 & Native & Graze & Graze & Graze & Graze & Graze & Graze \\
\hline W1 & 10.7 & 26.5 & Native & Graze & $\begin{array}{l}\text { Winter forage, } \\
\text { graze, hay }\end{array}$ & Graze, hay & Graze & Graze, hay & Graze, hay \\
\hline $6-13$ & 1.8 & 4.4 & Native & Graze & Graze & Graze & Graze & Graze & Graze \\
\hline $6-19$ & 3.8 & 9.3 & Native & Graze & Graze & Graze & Graze & Graze & Graze \\
\hline $6-20,6-21$ & 5.9 & 14.5 & $\begin{array}{l}\text { Cultivated } \\
\text { (forage oats) }\end{array}$ & $\begin{array}{l}\text { Summer cow } \\
\text { peas, poultry } \\
\text { litter, winter } \\
\text { oats (graze) }\end{array}$ & $\begin{array}{l}\text { Inorganic } \\
\text { fertilizer, } \\
\text { winter } \\
\text { oats (graze) }\end{array}$ & $\begin{array}{l}\text { Inorganic } \\
\text { fertilizer, } \\
\text { winter } \\
\text { oats (graze) }\end{array}$ & $\begin{array}{l}\text { Inorganic } \\
\text { fertilizer, } \\
\text { winter } \\
\text { oats (graze) }\end{array}$ & $\begin{array}{l}\text { Inorganic } \\
\text { fertilizer, } \\
\text { winter oats } \\
\text { (graze, hay) }\end{array}$ & $\begin{array}{l}\text { Inorganic } \\
\text { fertilizer, } \\
\text { winter oats } \\
\text { (graze) }\end{array}$ \\
\hline $5 x, 8$ & 16.6 & 40.9 & $\begin{array}{l}\text { Cultivated } \\
\text { (forage oats) }\end{array}$ & $\begin{array}{l}\text { Poultry litter, } \\
\text { winter oats } \\
\text { (graze) }\end{array}$ & $\begin{array}{l}\text { Inorganic } \\
\text { fertilizer, } \\
\text { winter oats } \\
\text { (graze) }\end{array}$ & $\begin{array}{l}\text { Inorganic } \\
\text { fertilizer, } \\
\text { winter oats } \\
\text { (graze) }\end{array}$ & $\begin{array}{l}\text { Inorganic } \\
\text { fertilizer, } \\
\text { winter oats } \\
\text { (graze) }\end{array}$ & $\begin{array}{l}\text { Inorganic } \\
\text { fertilizer, } \\
\text { winter oats } \\
\text { (graze, hay) }\end{array}$ & $\begin{array}{l}\text { Inorganic } \\
\text { fertilizer, } \\
\text { winter oats } \\
\text { (graze) }\end{array}$ \\
\hline
\end{tabular}

*Never plowed, but grazing pressure affected species composition. 


\section{Table 2}

Planning, implementation, and management timetable for the South Ranch under the conventional continuous grazing system and the North Ranch under a planned rest-rotation system.

\begin{tabular}{ll}
\hline Continuous grazing & Planned rest-rotation \\
\hline 2012 & 2012 \\
- Maintained two herds with 20 to 22 cows each & - Combined two herds into one with 28 to 30 cows based on NRCS Resource Inventory (May \\
based on traditional herd size and "contract" & 2012) and “contract" grazed 25 heifers for 47 days (animal unit days = 45.8 AUD ac ${ }^{-1}$ ). \\
grazed 10 heifers for 189 days (animal unit & - No-till drilled multispecies summer forage on cultivated grazed paddocks (May of 2012). \\
days $=66.5$ AUD ac ${ }^{-1}$ ). & - Added additional fence to facilitate rotational grazing (July of 2012). \\
- Drilled forage oats on cultivated grazed & - No-till drilled multispecies winter forage on cultivated grazed paddocks and grassland \\
paddocks (October of 2012). & paddocks 19 and 11A (October of 2012). \\
& - Installed additional water lines and troughs to provide water to each paddock (December \\
& of 2012).
\end{tabular}

2013

- Maintained two herds with 21 to 24 cows each based on traditional herd size (animal unit days $=66.2 \mathrm{AUD} \mathrm{ac}^{-1}$ ).

- Drilled forage oats on cultivated grazed paddocks (September of 2013).

- Maintained one herd with 28 to 30 cows and "contract" grazed 25 heifers for 28 days (animal unit days $=44.6 \mathrm{AUD} \mathrm{ac}^{-1}$ ).

- Further divided selected paddocks with additional temporary fence to facilitate rotational grazing.

- Applied poultry litter, plowed, and drilled multispecies summer forage on cultivated grazed paddocks (March of 2013).

- No-till drilled multispecies winter forage on cultivated grazed paddocks and grassland paddocks 19 and 11A (September of 2013).

\section{4}

- Maintained two herds with 22 to 27 cows each based on traditional herd size and "contract" grazed 17 heifers for 41 days (animal unit days $=73.9 \mathrm{AUD} \mathrm{ac}^{-1}$ ).

- Drilled forage oats on cultivated grazed paddocks (September of 2014).
2014

- Further divided selected paddocks with additional temporary fence to facilitate rotational grazing.

- No-till drilled multispecies summer forage on cultivated grazed paddocks (May of 2014).

- Increased herd size to 31 cows (July of 2014) and "contract" grazed 24 heifers for 119 days (animal unit days $=51.4$ AUD ac$^{-1}$ ).

- No-tilled drilled multispecies winter forage on cultivated grazed paddocks and grassland paddocks 19 and 11A (September of 2014).

- Replanted forage oats/wheat on cultivated grazed paddocks because of very poor stand (October of 2014).

\section{5}

- Maintained two herds with 27 cows each based on traditional herd size (animal unit days $=79.5 \mathrm{AUD} \mathrm{ac}^{-1}$ ).

- Drilled forage oats on cultivated grazed paddocks (September of 2015).

- Maintained two herds with 21 to 27 cows each based on traditional herd size (animal unit days $=70.7 \mathrm{AUD} \mathrm{ac}^{-1}$ ).

- Drilled forage oats on cultivated grazed paddocks (September of 2016).
2015

- No-till drilled multispecies summer forage on cultivated grazed paddocks (April of 2015).

- Increased herd size to 36 cows (July of 2015) and "contract" grazed 17 heifers for 74 days (animal unit days $=51.9 \mathrm{AUD} \mathrm{ac}^{-1}$ ).

- Applied poultry litter, scattered then plowed in multispecies winter forage on cultivated grazed paddocks (October of 2015).

\section{6}

- Increased herd size to 53 cows (March of 2016) and "contract" grazed 22 heifers for 280 days (animal unit days $=81.8 \mathrm{AUD} \mathrm{ac}^{-1}$ ).

- No-till drilled multispecies summer forage on cultivated grazed paddocks (June of 2016).

- Applied poultry litter, and scattered then plowed in multispecies winter forage on cultivated grazed paddocks (September of 2016). have been collected continuously at the Riesel Watersheds since the late 1930s, and the entire legacy database is publicly available at https:// www.ars.usda.gov/plains-area/temple-tx/ grassland-soil-and-water-research-laboratory/docs/hydrologic-data/ (Harmel et al. 2014). The intensive rainfall data collec- tion program, as described in Harmel et al. (2003), was continued throughout this project because rainfall timing and amount are important drivers in vegetative production and nutrient cycling.

The long-term average precipitation at Riesel is 35.2 in $(894 \mathrm{~mm}$ ) (Harmel et al.
2003), whereas annual precipitation ranged from 25.2 to 57.9 in (640 to $1,470 \mathrm{~mm}$ ) in the current study (figure 2).

Grassland Forage Production. Forage production was determined from $19.16 \mathrm{ft}^{2}(1.78$ $\mathrm{m}^{2}$ ) grazing exclosures established in five or six grassland paddocks for each grazing sys- 
Table 3

Land management for grassland and cultivated grazed paddocks on the North Ranch under the planned rest-rotation grazing system.

\begin{tabular}{|c|c|c|c|c|c|c|c|c|c|}
\hline Paddock & $\begin{array}{l}\text { Area } \\
\text { (ha) }\end{array}$ & $\begin{array}{l}\text { Area } \\
\text { (ac) }\end{array}$ & $\begin{array}{l}\text { Dominant } \\
\text { vegetation }\end{array}$ & $\begin{array}{l}\text { Recent } \\
\text { manage- } \\
\text { ment }\end{array}$ & 2012 & 2013 & 2014 & 2015 & 2016 \\
\hline $11 \mathrm{~A}$ & 2.9 & 7.1 & $\begin{array}{l}\text { Coastal } \\
\text { Bermuda }\end{array}$ & Hay & $\begin{array}{l}\text { Winter forage, } \\
\text { rotational graze }\end{array}$ & $\begin{array}{l}\text { Winter forage, } \\
\text { rotational graze }\end{array}$ & $\begin{array}{l}\text { Winter forage, } \\
\text { rotational graze }\end{array}$ & $\begin{array}{l}\text { Rotational } \\
\text { graze }\end{array}$ & $\begin{array}{l}\text { Rotational } \\
\text { graze }\end{array}$ \\
\hline 19 & 2.2 & 5.5 & $\begin{array}{l}\text { Coastal } \\
\text { Bermuda }\end{array}$ & Hay, graze & $\begin{array}{l}\text { Winter forage, } \\
\text { rotational graze, } \\
\text { poultry litter }\end{array}$ & $\begin{array}{l}\text { Winter forage, } \\
\text { rotational graze }\end{array}$ & $\begin{array}{l}\text { Winter forage, } \\
\text { rotational graze }\end{array}$ & $\begin{array}{l}\text { Rotational } \\
\text { graze }\end{array}$ & $\begin{array}{l}\text { Rotational } \\
\text { graze }\end{array}$ \\
\hline 5-1 & 13 & 32.2 & Kleingrass & Hay, graze & $\begin{array}{l}\text { Rotational graze, } \\
\text { poultry litter }\end{array}$ & $\begin{array}{l}\text { Rotational } \\
\text { graze }\end{array}$ & $\begin{array}{l}\text { Rotational } \\
\text { graze }\end{array}$ & $\begin{array}{l}\text { Rotational } \\
\text { graze }\end{array}$ & $\begin{array}{l}\text { Rotational } \\
\text { graze }\end{array}$ \\
\hline $\begin{array}{l}2-7,2,4 \\
15,5\end{array}$ & 20.3 & 50.2 & Native & Graze & $\begin{array}{l}\text { Rotational } \\
\text { graze }\end{array}$ & $\begin{array}{l}\text { Rotational } \\
\text { graze }\end{array}$ & $\begin{array}{l}\text { Rotational } \\
\text { graze }\end{array}$ & $\begin{array}{l}\text { Rotational } \\
\text { graze }\end{array}$ & $\begin{array}{l}\text { Rotational } \\
\text { graze }\end{array}$ \\
\hline $5-19,17$ & 8.6 & 21.3 & Native & Graze & $\begin{array}{l}\text { Rotational graze, } \\
\text { poultry litter } \\
\text { (5-19 only) }\end{array}$ & $\begin{array}{l}\text { Rotational } \\
\text { graze }\end{array}$ & $\begin{array}{l}\text { Rotational } \\
\text { graze }\end{array}$ & $\begin{array}{l}\text { Rotational } \\
\text { graze }\end{array}$ & $\begin{array}{l}\text { Rotational } \\
\text { graze }\end{array}$ \\
\hline Skull Hill & 8.2 & 20.2 & Native & Graze & $\begin{array}{l}\text { Rotational } \\
\text { graze }\end{array}$ & $\begin{array}{l}\text { Rotational } \\
\text { graze }\end{array}$ & $\begin{array}{l}\text { Rotational } \\
\text { graze }\end{array}$ & $\begin{array}{l}\text { Rotational } \\
\text { graze }\end{array}$ & $\begin{array}{l}\text { Rotational } \\
\text { graze }\end{array}$ \\
\hline 7-A, 16 & 10 & 24.9 & Native & Graze & $\begin{array}{l}\text { Rotational } \\
\text { graze }\end{array}$ & $\begin{array}{l}\text { Rotational } \\
\text { graze }\end{array}$ & $\begin{array}{l}\text { Rotational } \\
\text { graze }\end{array}$ & $\begin{array}{l}\text { Rotational } \\
\text { graze }\end{array}$ & $\begin{array}{l}\text { Rotational } \\
\text { graze }\end{array}$ \\
\hline $5-4,4-4$ & 1.8 & 4.4 & $\begin{array}{l}\text { Cultivated } \\
\text { (multispecies } \\
\text { forage) }\end{array}$ & $\begin{array}{l}\text { Winter } \\
\text { forage }\end{array}$ & $\begin{array}{l}\text { Poultry litter, } \\
\text { winter oats } \\
\text { (graze) }\end{array}$ & $\begin{array}{l}\text { No-till } \\
\text { summer forage, } \\
\text { no-till winter } \\
\text { oats (graze) }\end{array}$ & $\begin{array}{l}\text { Poultry litter, } \\
\text { summer forage } \\
\text { (graze), winter } \\
\text { forage (graze) }\end{array}$ & $\begin{array}{l}\text { No-till } \\
\text { summer forage } \\
\text { (graze), no-till } \\
\text { winter forage } \\
\text { (graze) }\end{array}$ & $\begin{array}{l}\text { No-till } \\
\text { summer } \\
\text { forage } \\
\text { (graze), } \\
\text { poultry litter, } \\
\text { winter forage } \\
\text { (graze) }\end{array}$ \\
\hline 5-2x, SW11 & 5.5 & 13.6 & $\begin{array}{l}\text { Cultivated } \\
\text { (multispecies } \\
\text { forage) }\end{array}$ & $\begin{array}{l}\text { Winter } \\
\text { forage }\end{array}$ & $\begin{array}{l}\text { Summer } \\
\text { cow peas, } \\
\text { poultry litter, } \\
\text { winter oats } \\
\text { (graze) }\end{array}$ & $\begin{array}{l}\text { No-till } \\
\text { summer } \\
\text { forage (graze), } \\
\text { no-till winter } \\
\text { oats (graze) }\end{array}$ & $\begin{array}{l}\text { Poultry litter, } \\
\text { summer } \\
\text { forage } \\
\text { (graze), } \\
\text { winter forage } \\
\text { (graze) }\end{array}$ & $\begin{array}{l}\text { No-till } \\
\text { summer } \\
\text { forage (graze), } \\
\text { no-till } \\
\text { winter forage } \\
\text { (graze) }\end{array}$ & $\begin{array}{l}\text { No-till } \\
\text { summer } \\
\text { forage } \\
\text { (graze), } \\
\text { poultry litter, } \\
\text { winter forage } \\
\text { (graze) }\end{array}$ \\
\hline
\end{tabular}

*Never plowed, but grazing pressure affected species composition.

tem.A $1.9 \mathrm{ft}^{2}\left(0.178 \mathrm{~m}^{2}\right)$ subplot within each exclosure, as well as $1.9 \mathrm{ft}^{2}$ plots in a transect extending from each exclosure, were clipped in the summer and in late fall/early winter to determine productivity and percentage vegetation left (residual forage). Forage production was not measured in the cultivated grazed paddocks on each ranch because we did not anticipate significant differences in forage production since we planted forage crops and because forage quality differences would be detected in the Grazingland Animal Nutrition Laboratory (GANLAB) data. In hindsight, we should have quantified forage production on the cultivated grazed paddocks, especially because of the poor stands of no-till cool-season forage in the planned-rest rotation system during the first three winters (2012 to 2013, 2013 to 2014, and 2014 to 2015) (discussed subsequently).
Differences in total annual forage production in the grassland paddocks were evaluated with two sample $t$-tests.

Livestock Diet Quality. Livestock diet quality was estimated from fresh manure samples taken approximately monthly from four to six cows in each herd (the single North herd, and two South herds). The samples were analyzed by the GANLAB (https://cnrit.tamu.edu/index.php/ganlab) 


\section{Figure 2}

Annual precipitation during the study period (2012 to 2016) and the two years preceding (2010 to 2011).

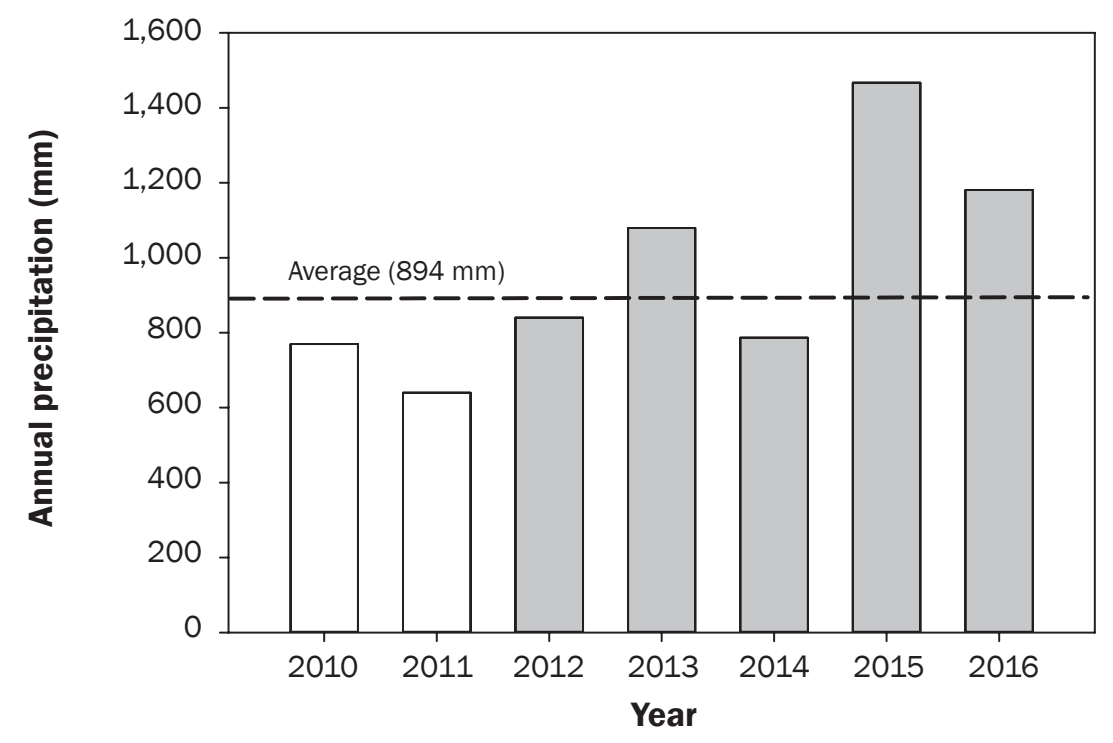

Legend

$\square$ Prior to study drought of 2011. Grassland forage production appeared to be higher under the planned rest-rotation system based on daily visual observations during the study. Forage production measurements from grazing exclosures supported this observation (figure 3); however, spatial variability between grassland paddocks prevented the detection of statistical differences in mean annual production. $T$-tests yielded no significant differences for any year $(p>0.301)$, the first two years with near normal rain $(p=0.328)$, the last two years with high rainfall $(p=0.689)$, or the entire data set $(p=0.646)$.

Differences in stocking rate and fertilizer application rate (discussed subsequently) no doubt influenced these results. Stocking rate under conventional grazing remained relatively consistent as per traditional management preference (66.5 to 70.7 animal unit days [AUD] $\mathrm{ac}^{-1}$ [164 to 175 AUD $\left.\mathrm{ha}^{-1}\right]$ ), whereas the stocking rate under the planned rest-rotation system was flexible starting at 44.6 to 45.8 AUD ac ${ }^{-1}$ (110 to 113 AUD ha ${ }^{-1}$ ) in 2012 to 2013 , then increasing to 51.4 to 51.9 AUD ac ${ }^{-1}$ (127 to 128 AUD $\mathrm{ha}^{-1}$ ) for 2014 to 2015 , and to 81.8 AUD ac (202 AUD ha ${ }^{-1}$ ) in 2016 (table 2). The higher stocking rate for conventional grazing until 2016 contributed to the visual observation of less grassland forage production; however, since production data were collected from grazing exclosures, any differences can be attributed to the treatment effect (grazing system change). Whereas about 50 ac (20.2 ha) of grassland in both ranches received fertilizer in 2012, grassland fertilization continued only under the continuous grazing system. From 2013 to 2016, between 45 ac (18 ha; 21\%) and 97 ac (39 ha; 46\%) of the grassland under conventional grazing were fertilized annually. Fertilizer application would have increased forage production on these pastures, which increases the likelihood the planned rest-rotation system did increase pasture forage production.

A higher percentage of standing forage was left by planned rest-rotation grazing after the growing season $(63 \% \pm 21 \%)$ and was available as dry matter for the winter compared to the continuous grazing system (34\% $\pm 26 \%$ ). How much of this standing dry matter was utilized by cattle is unknown, but observations indicated a combination of dry matter consumption and trampling as cattle were concentrated in smaller paddocks. We also observed increased dry matter utilization 
when better balanced with protein sources (e.g., growing forage, syrup, and cake) except for Kleingrass (Panicum coloratum; paddock $5-1)$, which cattle refused to eat in the dormant season.

Livestock Diet Quality. As shown in table 4 , average forage quality was higher for the conventional grazing system for both crude protein $(p=0.010)$ and digestible organic matter $(p=0.077)$. We observed the same trend in the coldest months (January and February) for both crude protein $(p=0.023)$ and digestible organic matter $(p=0.046)$. The difference during the winter high stress period, characterized by dormant pasture vegetation and nursing calves, is attributed to unlimited baled hay fed freely under conventional grazing management. Additionally, very poor stands of multispecies, cool-season forage on cultivated grazed paddocks reduced diet quality for cattle under the planned rest-rotation system in the winters of 2012 to 2013, 2013 to 2014, and 2014 to 2015 (discussed in Lessons Learned section). In contrast, livestock diet quality did not differ between grazing strategies in the summer growing season period (August to September) across years, which is consistent with prior research (Walker et al. 1989; Holechek et al. 2000; Briske et al. 2008). The lack of significant differences during the summer, despite sugar cane aphids destroying most of the planted forage in the planned rest-rotation system in 2014, highlights the success of no-tilling warm-season, multispecies forages in cultivated grazed paddocks.

Cattle Response. As shown in table 4, mean BCSs were lower for cows under planned

\section{Figure 3}

Total annual forage production in grassland paddocks measured from grazing exclosures for the North Ranch (planned rest-rotation) and South Ranch (conventional). The black dots represent

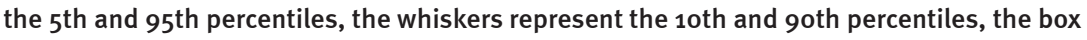
boundaries represent the $25^{\text {th }}$ and $75^{\text {th }}$ percentiles, the center line is the median, and the dotted line is the mean.

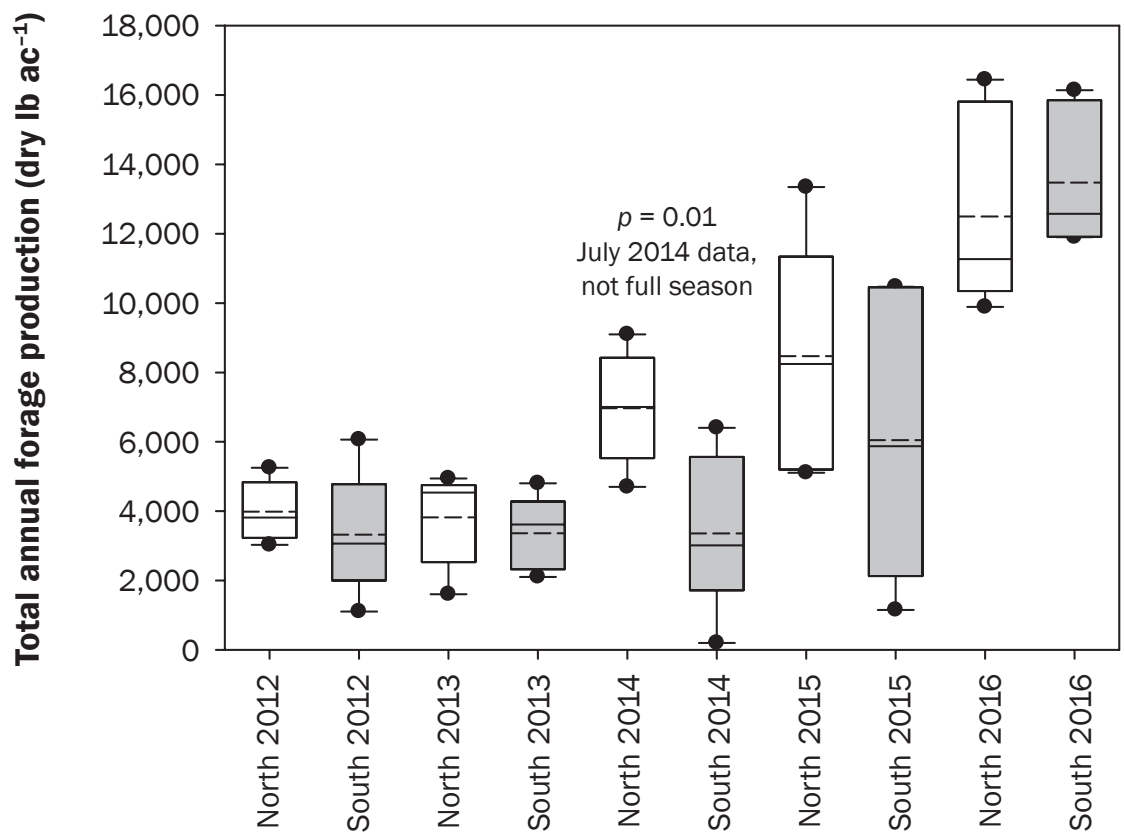

Ranch year

rest-rotation grazing $(p=0.019)$, and the variability was higher $(p=0.021)$; however, no significant statistical differences were evident in the two high stress periods (summer with hot, dry conditions represented by August through September data, $p=0.514$; winter cold conditions with dormant vegetation and nursing calves represented by
January through February data, $p=0.132$ ). Cattle on both ranches fared well (high BCS) in the warm season, but body conditions were lower under the planned rest-rotation system in the winter. The practical question is whether allowing the BCS to decrease to a lower, but certainly healthy level, is good or bad in terms of economic returns. There

Table 4

Livestock diet quality (mean $\pm \mathrm{sd}$ ), as indicated by crude protein and digestible organic matter (DOM), along with body condition scores (BCS), for the planned rest-rotation and conventional continuous grazing systems.

\begin{tabular}{|c|c|c|c|c|c|c|c|}
\hline \multirow[b]{2}{*}{ Months } & \multirow[b]{2}{*}{$\begin{array}{l}\text { Mean/ } \\
\text { range }\end{array}$} & \multicolumn{2}{|c|}{ Crude protein (\%) } & \multicolumn{2}{|l|}{ DOM (\%) } & \multicolumn{2}{|l|}{ BCS } \\
\hline & & $\begin{array}{l}\text { Planned } \\
\text { rest-rotation }\end{array}$ & Conventional & $\begin{array}{l}\text { Planned } \\
\text { rest-rotation }\end{array}$ & Conventional & $\begin{array}{l}\text { Planned } \\
\text { rest-rotation }\end{array}$ & Conventional \\
\hline \multirow[t]{3}{*}{ All } & Mean & $8.2 \pm 2.5$ & $9.6 \pm 3.4$ & $61.4 \pm 3.5$ & $62.7 \pm 4.6$ & $6.6 \pm 0.5$ & $6.8 \pm 0.3$ \\
\hline & Range & 4.7 to 15.9 & 4.0 to 19.6 & 55.8 to 70.9 & 54.9 to 78.8 & 5.0 to 7.4 & 5.8 to 7.0 \\
\hline & & \multicolumn{2}{|c|}{$(p=0.010)$} & \multicolumn{2}{|c|}{$(p=0.077)$} & \multicolumn{2}{|c|}{$(p=0.019)$} \\
\hline Aug. to Sept. & Mean & $7.6 \pm 1.7$ & $8.1 \pm 2.0$ & $61.4 \pm 3.1$ & $61.3 \pm 1.7$ & $6.8 \pm 0.2$ & $6.9 \pm 0.1$ \\
\hline \multirow[t]{3}{*}{ Jan. to Feb. } & Mean & $8.4 \pm 2.6$ & $12.8 \pm 3.7$ & $61.3 \pm 4.0$ & $66.6 \pm 4.4$ & $6.0 \pm 0.6$ & $6.6 \pm 0.4$ \\
\hline & Range & 5.3 to 11.9 & 8.4 to 18.3 & 56.5 to 67.4 & 60.5 to 72.5 & 5.0 to 6.5 & 6.0 to 7.0 \\
\hline & & \multicolumn{2}{|c|}{$(p=0.023)$} & \multicolumn{2}{|c|}{$(p=0.046)$} & \multicolumn{2}{|c|}{$(p=0.132)$} \\
\hline
\end{tabular}


is an ongoing debate among producers as to whether it is worth the extra feed costs to keep cow body conditions at such a high level during the winter. A decrease in calving rates is a good indicator that body condition decline is excessive. In this study, BCS remained fairly high for both ranches, and no difference in calving rates was observed.

Weights for 2013 to 2016 for each herd are shown in figure 4 . Average annual steer calf weights ranged from 632 to $671 \mathrm{lb}$ (286.7 to $304.4 \mathrm{~kg}$ ) under planned rest-rotation grazing and from 617 to $839 \mathrm{lb}$ (280 to 380.6 $\mathrm{kg}$ ) for conventional continuous grazing. The only significant difference in mean weights ( $p=0.0001)$ occurred in 2014 when the calves under conventional grazing (avg. 839 lb) outweighed calves under planned rest-rotation grazing (avg. $654 \mathrm{lb}$ [296.6 kg]). This difference is likely attributed to a very poor stand and limited productivity of the winter multispecies forage and to seemingly very low palatability of the standing Kleingrass hay in the adjacent paddock used for winter grazing that year. In response, supplemental protein was used but likely not quickly enough. In contrast, grazing oats and unlimited hay under conventional grazing provided higher quality feed thus benefitting the cows and calves.

Economics. Cost and revenue data for the two ranches are shown in table 5. Converting from conventional continuous grazing to the planned rest-rotation system led to substantial differences in costs and revenue. For example, labor costs were reduced by $48 \%$ with planned rest-rotation grazing mostly due to less time spent plowing and feeding hay. Similarly, feed costs were reduced (41\%), although more supplemental protein feed was used because less hay was feed, which is partially attributed to more "standing hay." Machinery and fuel costs were reduced by $46 \%$ under the planned rest-rotation system because plowing was reduced even though more time was spent planting forage crops. Fertilizer costs were reduced by $44 \%$ even though more expensive organic fertilizers were applied; however, in hindsight, the implemented reduction in fertilizer rates was too substantial. In contrast, additional capital costs were required under the planned rest-rotation system to install additional fencing and watering infrastructure to facilitate rotational grazing. Seed costs were also higher (160\%) because of planting cool- and warm-season forage crops on cultivated grazed paddocks and on selected grassland

\section{Figure 4} Steer weights for the North Ranch planned rest-rotation grazing system and the South Ranch conventional grazing system $\left({ }^{*} p=0.001\right)$.

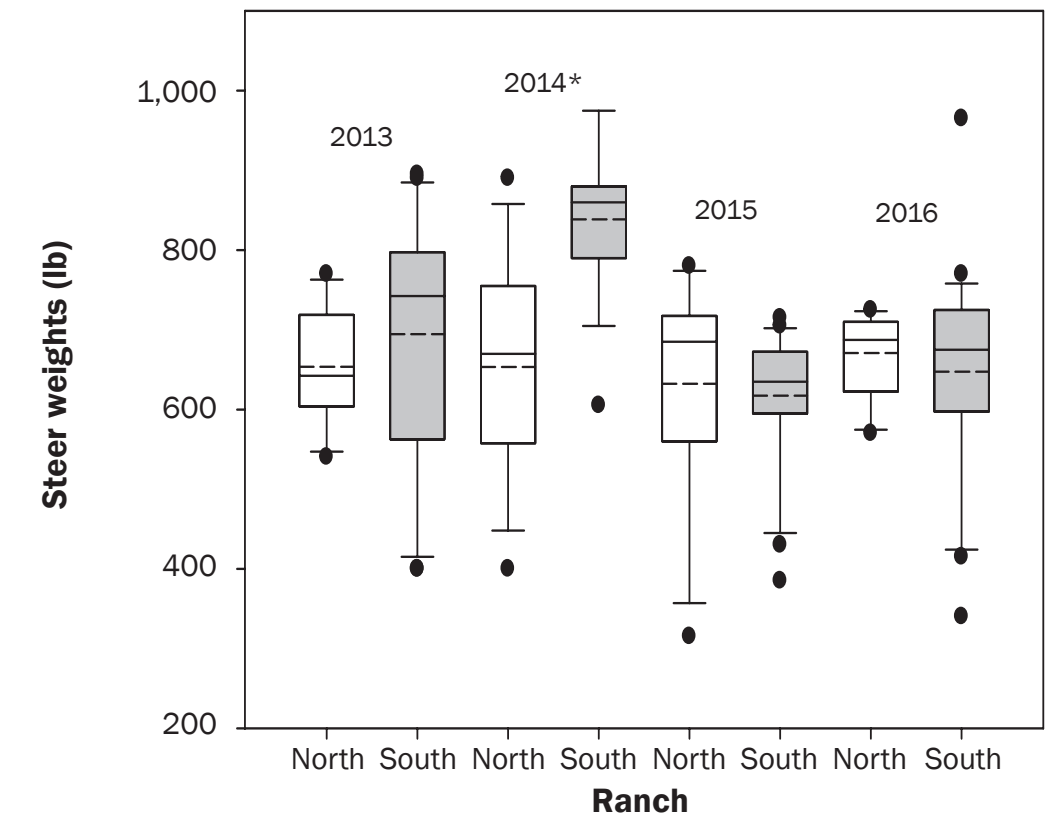

paddocks in the cool-season. Overall, annual average costs for the planned rest-rotation system were US $\$ 37,050$ (US $\$ 132 \mathrm{ac}^{-1}$ [US\$53 ha $\mathrm{ha}^{-1}$ ) and for continuous grazing were US $\$ 47,472$ (US $\$ 168 \mathrm{ac}^{-1}$ [US $\$ 68 \mathrm{ha}^{-1}$ ), which resulted in a $22 \%$ cost reduction.

Whereas the costs were lower for the planned rest-rotation system, the revenue was also lower. The revenue fluctuated annually on both ranches based on cattle prices, calf numbers, and number of older cows sold. The annual average revenue from selling calves and older cows was US $\$ 31,294$ for the planned rest-rotation system compared to US $\$ 45,735$ for continuous grazing. Revenue from cattle sales for the planned rest-rotation system was lower because of lighter calves, especially in 2014, and fewer cows (smaller herd) resulted in fewer calves sold. Increased grassland vegetation production and supplemental multispecies forage in the warm-season did allow additional contract grazing for the planned rest-rotation system, which provided additional revenue of US $\$ 1,875 \mathrm{yr}^{-1}$. This added revenue potential is akin to adding yearlings to cow-calf operations described by Bastian et al. (2018), which allows more effective temporal matching of available forage to grazing demands and flexibility to optimize utilization under increased forage production. Mean annual revenue for planned rest-rotation grazing was US $\$ 38,548$ (US\$137 $\mathrm{ac}^{-1}$ [US\$56 ha $\mathrm{ha}^{-1}$ ) compared to
US\$48,971 (US\$174 $\mathrm{ac}^{-1}$ [US\$70 ha ${ }^{-1}$ ) for conventional grazing, which is a $21 \%$ reduction in revenue.

Overall, during this five-year study, costs were $22 \%$ lower but revenue was 21\% lower for the planned rest-rotation system compared to the conventional grazing system. As a result, the average annual profit for both ranches was approximately US $\$ 5.32 \mathrm{ac}^{-1}$ (US $\$ 2.15 \mathrm{ha}^{-1}$ ) and was unaffected by the change in management strategy.

Soil Health. During this five-year study, one-day $\mathrm{CO}_{2}$ (soil respiration) indicated significant increases over time in grassland paddocks under both grazing systems, for cultivated grazed paddocks under planned rest-rotation grazing and for the native prairie control (tables 6 and 7). These increases tracked increases in annual rainfall. Cultivated grazed paddocks under conventional continuous grazing were the only land use without a significant increase in soil health. This indicates detrimental effects on soil respiration from the traditional practice of planting monoculture grazed oats, applying inorganic fertilizer, and associated soil tillage. No significant differences in mean soil respiration were observed between summer and winter, nor between corresponding land uses on the two grazing systems (tables 6 and 7).

Results for WEOC showed no significant trends over the five-years (tables 6 and 7). Although none of the slopes of the lin- 
Table 5

Results of economic comparison between the planned rest-rotation grazing system and the conventional continuous grazing system.

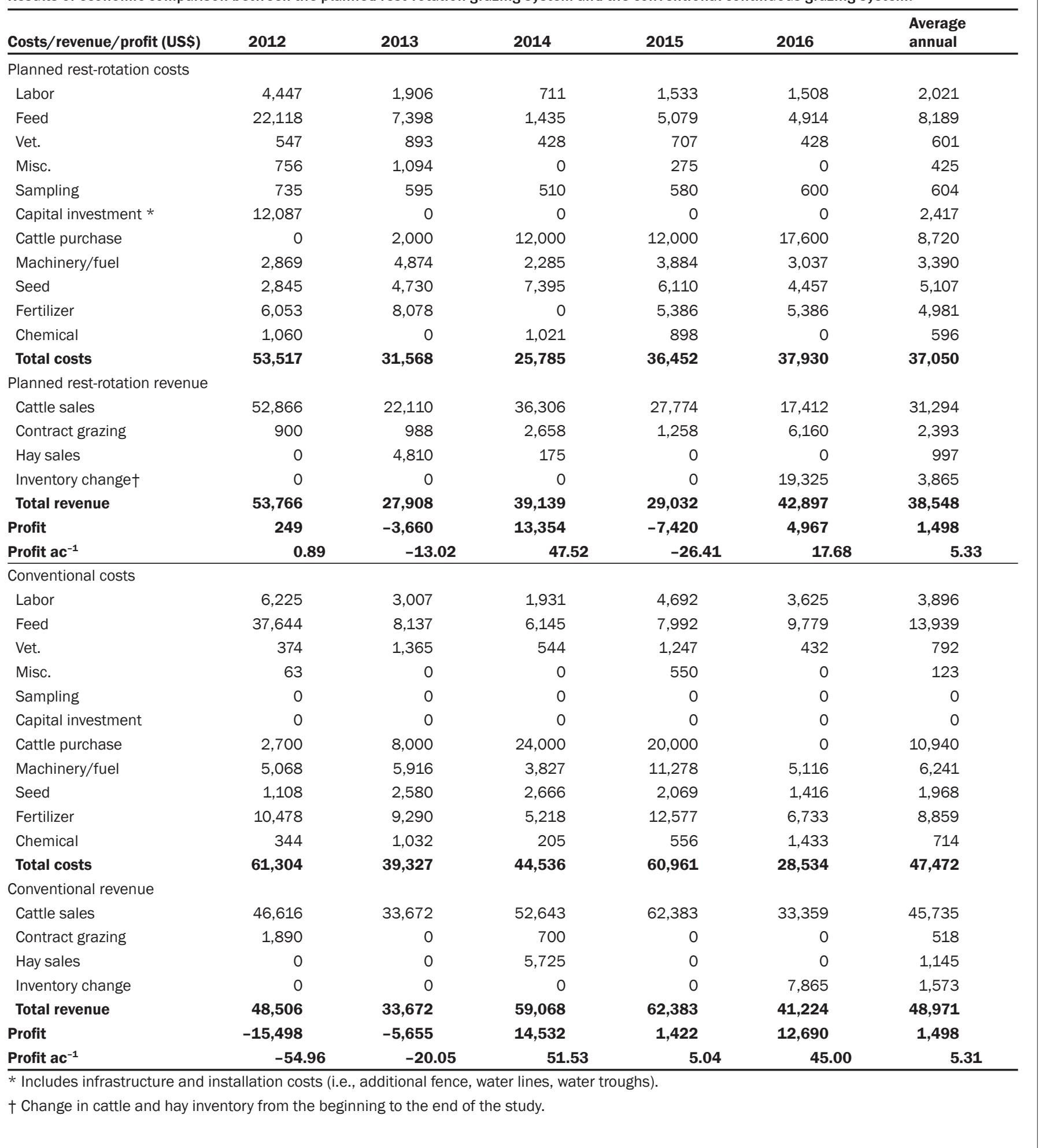

ear relationship of WEOC over time were statistically significant, the positive slopes (increases) under planned rest-rotation grazing were larger than under continuous grazing, indicating possible treatment effects. Average soil WEOC concentration was significantly higher in the summer than in the winter for the native prairie and cultivated grazed paddocks under both systems but not the grassland paddocks. The only significant difference in WEOC occurred in the winter when WEOC for cultivated grazed paddocks 
Table 6

Mean soil health indicators during summer and winter for the grassland paddocks under the planned rest-rotation grazing system and the conventional continuous grazing system.

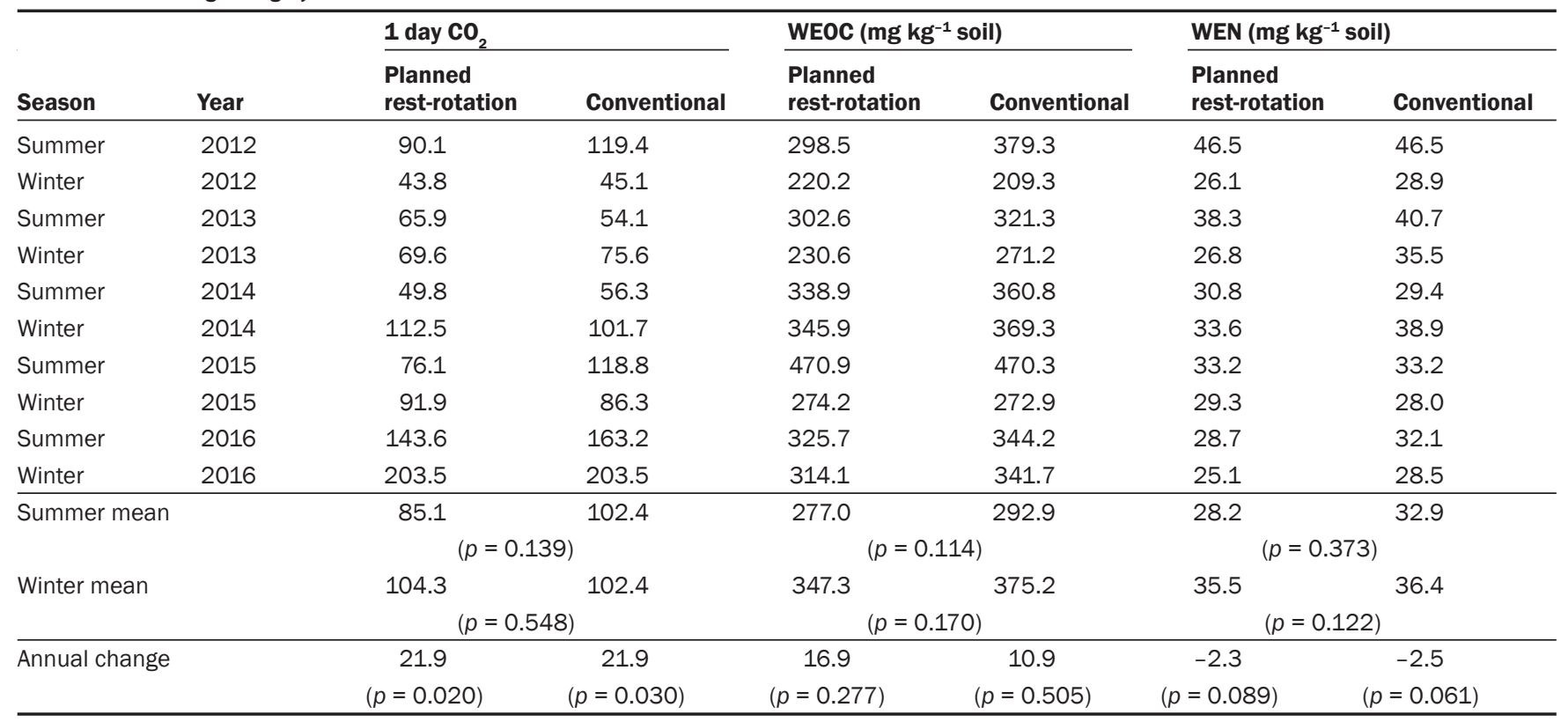

Notes: $\mathrm{CO}_{2}=$ carbon dioxide. $\mathrm{WEOC}=$ water extractable organic carbon. $\mathrm{WEN}=$ water extractable nitrogen.

under planned rest-rotation grazing was greater than under continuous grazing ( $p=$ $0.010)$. This again indicates a possible treatment effect and improvement in soil $\mathrm{C}$ due to management changes, including planting both cool- and warm-season forage on the grazed cultivated paddocks instead of the traditional practice of summer fallow.

During the study, WEN showed significant decreases over time in grassland paddocks under both planned rest-rotation $(p=0.089)$ and continuous grazing $(p=0.061)$. The linear relationships for the native prairie and cultivated grazed paddocks on both ranches also had negative slopes, but the decreases over time were not significant. The increased rainfall over the study and resulting increased leaching potential (Harmel et al. 2019) likely contributed to the decreases in WEN. No significant differences in mean WEN concentrations were observed between summer and winter nor between corresponding land uses under the two grazing systems.

Overall, these results show the potential for soil health improvement due to changes in management practices, especially for cultivated grazed paddocks. The observation that soil health changes were more evident in cultivated grazed paddocks than on grassland paddocks is reasonable because the management changes (e.g., conversion from summer fallow to multispecies, warm-season forage, no-till, and organic fertilizer) were more sweeping. Another indication that planned rest-rotation has the potential to increase soil health is that initial values for all three indicators (one-day $\mathrm{CO}_{2}, \mathrm{WEOC}$, and WEON) were lower for planned rest-rotation, but as the study progressed many values were greater than for the continuous grazing treatment, especially on cultivated grazed paddocks. Also, the annual average rate of increase in one-day $\mathrm{CO}_{2}$ and WEOC for planned rest-rotation was greater than for continuous grazing.

Whether or not changes in management will result in continued soil health improvement on grassland is unclear based on the initial five years of this case study. In another study on a Texas Vertisol, Teague et al. (2019a) showed a lack of increases in soil fertility and microbiological activity with Bermuda grass pasture overseeded in the winter with multispecies forage crops. While another site in the study did see increases in soil fertility and microbiological activity, the authors speculated that the Vertisol would need to experience increases in soil $\mathrm{C}$ before increases in soil fertility and microbiological activity would occur.

Lessons Learned. This case study was designed to evaluate opportunities and challenges associated with the conversion from conventional continuous grazing to a planned rest-rotation grazing system under humid subtropical conditions. This conversion incorporated substantial management changes on cultivated grazed paddocks (i.e., from conservation tillage and drilling to no-tilling; from monoculture cool-season oats to continuous-cropping with multispecies forage mixes; from inorganic fertilizer at traditional rates to no fertilizer or organic fertilizer at reduced rates). The combined effects of these changes produced very poor stands of cool-season forage on cultivated grazed paddocks on the North Ranch under the planned rest-rotation system relative to the conventional system, especially during the winters of 2012 to 2013, 2013 to 2014, and 2014 to 2015 . In these same years, the conventional practices of conservation tillage, sowing, and fertilization of monoculture oats on the South Ranch produced abundant cool-season forage. While a reduction in cool-season forage was anticipated due to the transition to no-till, the surprisingly severe reduction from abundant forage to very little forage during 2012 to 2014 adversely affected cattle responses and associated economic returns for the planned rest-rotation system. The very poor stands occurred even when a high proportion of oats and wheat (Triticum aestivum L.) were planted in the multispecies mixture and as we became more familiar with the no-till drill. Our continued frustration with stands of cool-season forage on cultivated 
Table 7

Soil health indicators during summer and winter for the cultivated grazed paddocks under the planned rest-rotation grazing system and the conventional continuous grazing system.

\begin{tabular}{|c|c|c|c|c|c|c|c|}
\hline \multirow[b]{2}{*}{ Season } & \multirow[b]{2}{*}{ Year } & \multicolumn{2}{|l|}{1 day $\mathrm{CO}_{2}$} & \multicolumn{2}{|c|}{ WEOC (mg kg ${ }^{-1}$ soil) } & \multicolumn{2}{|c|}{ WEN (mg kg-1 soil) } \\
\hline & & $\begin{array}{l}\text { Planned } \\
\text { rest-rotation }\end{array}$ & Conventional & $\begin{array}{l}\text { Planned } \\
\text { rest-rotation }\end{array}$ & Conventional & $\begin{array}{l}\text { Planned } \\
\text { rest-rotation }\end{array}$ & Conventional \\
\hline Summer & 2012 & 33.6 & 60.3 & 187.2 & 230.9 & 24.8 & 30.5 \\
\hline Winter & 2012 & 35.3 & 21.3 & 148.6 & 102.4 & 18.9 & 31.0 \\
\hline Summer & 2013 & 40.5 & 37.5 & 224.1 & 250.1 & 48.3 & 31.8 \\
\hline Winter & 2013 & 47.6 & 46.4 & 128.5 & 88.9 & 15.1 & 34.8 \\
\hline Summer & 2014 & 21.1 & 13.9 & 229.5 & 197.9 & 23.0 & 20.4 \\
\hline Winter & 2014 & 20.4 & 25.9 & 220.5 & 187.8 & 24.4 & 45.4 \\
\hline Summer & 2015 & 30.6 & 37.2 & 312.1 & 271.7 & 23.6 & 24.8 \\
\hline Winter & 2015 & 62.2 & 54.5 & 192.1 & 183.7 & 21.0 & 22.1 \\
\hline Summer & 2016 & 66.4 & 51.9 & 234.0 & 192.6 & 25.2 & 24.7 \\
\hline Winter & 2016 & 64.6 & 48.5 & 232.2 & 177.3 & 24.2 & 19.4 \\
\hline \multicolumn{2}{|c|}{ Summer mean } & 38.4 & 40.2 & 184.4 & 148.0 & 20.7 & 30.5 \\
\hline & & \multicolumn{2}{|c|}{$(p=0.170)$} & \multicolumn{2}{|c|}{$(p=0.655)$} & \multicolumn{2}{|c|}{$(p=0.534)$} \\
\hline \multirow{2}{*}{\multicolumn{2}{|c|}{ Winter mean }} & 46.0 & 39.3 & 237.4 & 228.6 & 29.0 & 26.4 \\
\hline & & \multicolumn{2}{|c|}{$(p=0.821)$} & \multicolumn{2}{|c|}{$(p=0.010)$} & \multicolumn{2}{|c|}{$(p=0.126)$} \\
\hline \multirow{2}{*}{\multicolumn{2}{|c|}{ Annual change }} & 6.67 & 2.21 & 16.0 & 4.0 & -0.82 & -2.37 \\
\hline & & $(p=0.063)$ & $(p=0.527)$ & $(p=0.146)$ & $(p=0.764)$ & $(p=0.688)$ & $(p=0.169)$ \\
\hline
\end{tabular}

Notes: $\mathrm{CO}_{2}=$ carbon dioxide. $\mathrm{WEOC}=$ water extractable organic carbon. WEN = water extractable nitrogen.

grazed field led to adaptive management decision and return to conventional planting and tillage in 2016 and poultry litter application in 2015 and 2016. In hindsight, we should have either made more modest changes or incremental changes to tillage, planting, and fertilization related to cool-season forage in the planned rest-rotation system, rather than the abrupt shift. It is interesting to note that this same no-till planting and limited fertilization strategy produced good stands of cool-season multispecies forage in grassland paddocks and of warm-season multispecies forages in cultivated grazed paddocks.

Another management factor that likely hurt cattle response under planned rest-rotation grazing was nutritional supplementation in the cool-season, the need for which was exacerbated by the limited cool-season forage in the cultivated grazed paddocks, as discussed previously. In retrospect, we focused too intently on the goal of cost savings from reduced hay supplementation assuming standing hay provided adequate dry matter. As a result, we provided less than optimal hay and/or protein supplement to meet nutritional requirements for the cows and calves. In addition, we should have collected manure samples more frequently for GANLAB analysis during the high-stress cool-season and responded quicker with supplemental protein for the planned rest-rotation system. The cost of additional protein or hay supplementation and sample analysis during the winter would likely have been well worth it.

We should have also been even more responsive to observations of increased forage production and carrying capacity under the planned rest-rotation system. The NRCS Resource Inventory conducted for the planned rest-rotation system at the beginning of the study, near the end of the 2011 drought, resulted in a low initial stocking rate. Increasing rainfall and apparent treatment impacts increased vegetation production, but our adaptive management response of increased stocking rate lagged the ecological responses. This led to a mismatch in forage availability and animal demand. More proactive adaptive management, associated with science-informed monitoring of forage production to inform decision-making, would have accelerated stocking rate increases in the planned rest-rotation system. This would have increased the number of calves sold and thus increased revenue and likely would have offset cattle purchase and production costs. This adaptive management approach, which attempts to balance herd size and forage availability on an annual basis instead or maintaining a consistent herd size despite annual variability was difficult to effectively implement because of traditional management preferences ingrained over decades.

\section{Summary and Conclusions}

In humid, subtropical environments with moderate to high forage production potential, traditional beef cattle production systems continue to rely on continuous grazing with high stocking rates; however, many producers are exploring alternative systems to increase resiliency, reduce costs, and/or improve shortand long-term profitability in the face of drought potential and market pressure. Thus, this case study was designed to provide muchneeded science related to alternative grazing systems and to evaluate real-world challenges and opportunities for beef cattle operations transitioning from conventional management (year-round continuous grazing) to an aspirational management strategy that utilized planned rest-rotational grazing along with continuous forage cropping on cultivated grazed paddocks and overseeding grassland paddocks in the cool-season, both with multispecies mixes, to reduce reliance on hay and high rates of commercial fertilizer application. Results indicated the potential for increased grassland forage production and soil health improvement on cultivated grazed paddocks under the planned rest-rotation system. The transition successfully reduced costs and maintained profits; however, the conventional continuous grazing system maintained higher body condition scores of cows during the winter because of unlimited feeding of baled 
hay and higher cool-season forage quality in the cultivated grazed paddocks.

Lessons learned highlight the importance of producer decisions and steep learning curves related to major management transitions, including incorporating adaptive management within and between years (Briske et al. 2011b; Derner et al. 2021). The present results confirm that adaptive management should incorporate a basic understanding of agroecosystem dynamics, consideration of diverse constraints resulting from spatial and temporal variability, and determination of appropriate short- and long-term indicators and responses to achieve ecosystem health and profitability goals (Teague et al. 2011). The near-instantaneous shift from an entrenched "business as usual" approach of continuous grazing and conventional management of grassland and cultivated grazed paddocks to adaptive management employing planned rest-rotation grazing and substantial management changes proved extremely challenging. The ingrained approaches and experiential knowledge acquired over decades by managers in this region, along with increased management intensity, highlighted the importance of sociological factors or human dimensions as recently emphasized by Derner and Augustine (2016) and Wilmer et al. (2018a, 2018b).

Further research is suggested on the hydro-climatic conditions under which rotational grazing (or alternative systems) are more or less likely to be successful. Whereas past comparisons have focused on the basic question as to which system is better, we recommend expanded research to understand the role of the hydro-climatic variables (i.e., amount and timing of precipitation in relation to temperature, day length, and growing season timing and duration), which we propose may be the major driver in differences in grazing system success. Research is also needed on the influence of initial conditions on rates of soil health and vegetation response resulting from changes in grazing management systems and on the most important grazing management actions when transitioning from conventional to alternative grazing systems considering the ranch-level, socio-economic complexities and tradeoffs involved.

\section{Acknowledgements}

Initial funding for this research was provided by the USDA Natural Resources Conservation Service (NRCS) Texas and the Grazing Lands Conservation Initiative through the
Conservation Innovative Grant program, and this support is gratefully recognized. This research was a contribution from the Long-Term Agroecosystem Research (LTAR) network. LTAR is supported by the United States Department of Agriculture. The USDA is an equal opportunity provider and employer.

\section{References}

Allen, P.M., R.D. Harmel, J. Arnold, B. Plant, J. Yeldermann, and K. King. 2005. Field data and flow system response in clay (Vertisol) shale terrain, north central Texas, USA. Hydrological Processes 19:2719-2736.

Arnold, J.G., K.N. Potter, K.W. King, and P.M. Allen. 2005. Estimation of soil cracking and the effect on surface runoff in a Texas Blackland Prairie watershed. Hydrological Processes 19:589-603.

Bastian, C.T., J.P. Ritten, and J.D. Derner. 2018. Ranch profitability given increased precipitation variability and flexible stocking. Journal of the American Society of Farm Managers and Rural Appraisers 2018:122-139.

Briske, D.D., J.D. Derner, J.R. Brown, S.D. Fuhlendorf, W.R. Teague, K.M. Havstad, R.L. Gillen, A.J. Ash, and W.D. Willms. 2008. Rotational grazing on rangelands: Reconciliation of perception and experimental evidence. Rangeland Ecology and Management 61(1):3-17.

Briske, D.D., J.D. Derner, D.G. Milchunas, and K.W. Tate. 2011a. An evidence-based assessment of prescribed grazing practices. In Conservation Benefits of Rangeland Practices: Assessment, Recommendations, and Knowledge Gaps, ed. D.D. Briske. Washington, DC: USDA Natural Resources Conservation Service.

Briske, D.D., N.F. Sayre, L. Huntsinger, M. FernandezGimenez, B. Budd, and J.D. Derner. 2011b. Origin, persistence, and resolution of the rotational grazing debate: Integrating human dimensions into rangeland research. Rangeland Ecology and Management 64(4):325-334.

Delgado, J.A., P.M. Groffman, M.A. Nearing, T. Goddard, D. Reicosky, R. Lal, N.R. Kitchen, C.W. Rice, D Towery, and P. Salon. 2011. Conservation practices to mitigate and adapt to climate change. Journal of Soil and Water Conservation 66(4):118A-129A. https://doi. org/10.2489/jswc.66.4.118A.

Derner, J.D., and D.J.Augustine. 2016. Adaptive management for drought on rangelands. Rangelands 38:211-215.

Derner, J.D., D.J. Augustine, D.D. Briske, H. Wilmer, L.M. Porensky, M.E. Fernandez-Gimenez, D. Peck, J.R. Ritten, and the CARM Stakeholder Group. 2021 Can collaborative adaptive management improve cattle production in multi paddock grazing systems. Rangeland Ecology and Management 75:1-8.

Franzluebbers, A.J. 2007. Integrated crop-livestock systems in the Southeastern USA. Agronomy Journal 99:361-372.

Gerrish, J. 2004. Management-intensive Grazing, the Grassroots of Grass Farming. Ridgeland, MO: Green Park Press.
Gunter, S.A., and N.A. Cole. 2016. Invited Review: Getting more information from your grazing research beyond cattle performance. The Professional Animal Scientist 32:31-41.

Haney, R.L., W.F. Brinton, and E. Evans. 2008. Soil $\mathrm{CO}_{2}$ respiration: Comparison of chemical titration, $\mathrm{CO}_{2}$ IRGA analysis, and the Solvita gel system. Renewable Agriculture and Food Systems 23(2):171-176.

Haney, R.L., A.J. Franzluebbers, F.M. Hons, and D.A Zuberer. 2004. Soil carbon and nitrogen mineralization: Influence of drying temperature. Soil Science Society of America Journal 68:489-492.

Haney, R.L., A.J. Franzluebbers, V.L. Jin, M-V. Johnson, E.B. Haney, M.J. White, and R.D. Harmel. 2012. Soil organic C:N vs. water-extractable organic C:N. Open Journal of Soil Science 2:269-274.

Haney, R.L., and E.B. Haney. 2010. Simple and rapid laboratory method for rewetting dry soil for incubations. Communications in Soil Science and Plant Analysis 41(12):1493-1501.

Haney, R.L., E.B. Haney, L.R. Hossner, and J.G. Arnold. 2006. Development of a new soil extractant for simultaneous phosphorus, ammonium, and nitrate analysis. Communications in Soil Science and Plant Analysis 37:1511-1523.

Harmel, R.D., R.L. Haney, D.R. Smith, M.W. White, and K.W. King. 2014. USDA-ARS Riesel Watersheds, Riesel, TX, USA: Water quality research database. Water Resources Research 50:8374-8382.

Harmel, R.D., K.W. King, C.W. Richardson, and J.R. Williams. 2003. Long-term precipitation analyses for the central Texas Blackland prairie. Transactions of the ASAE 46(5):1381-1388.

Harmel, R.D., D.R. Smith, R.L. Haney, and P.M. Allen. 2019. Comparison of nutrient loss pathways: Runoff and seepage flow in Vertisols. Hydrological Processes 33:2384-2393.

Havstad, K.M., D.P.C. Peters, R. Skaggs, J. Brown, B. Bestelmeyer, E. Frederickson, J. Herrick, and J. Wright. 2007. Ecological services to and from rangelands of the United States. Ecology Economics 64:261-268.

Herd, D.B., and L.R. Sprott. 1986. Body condition, nutrition and reproduction of beef cows. Texas FARMER Collection. College Station, TX: Texas Agricultural Extension Service. https://oaktrust.library.tamu. edu/bitstream/handle/1969.1/129135/Bull1526a. pdf? sequence $=14$.

Holechek, J.L., H. Gomes, F. Molinar, D. Galt, and R. Valdez. 2000. Short-duration grazing: The facts in 1999. Rangelands Archives 22(1):18-22.

Jacobo, E.J., A.M. Rodriguez, N. Bartoloni, and V.A. Deregibus. 2006. Rotational grazing effects on rangeland vegetation at a farm scale. Rangeland Ecology and Management 59(3):249-257.

Jakoby, O., M.F. Quaas, S. Baumgärtner, and K Frank. 2015. Adapting livestock management to spatio-temporal 
heterogeneity in semi-arid rangelands. Journal of Environmental Management 162:179-189.

Janzen, H.H. 2011. What place for livestock on a re-greening earth? Animal Feed Science and Technology 166-167:783-796.

Kachergis, E., J.D. Derner, L.M. Roche, K.W. Tate, M.N. Lubell, R.D. Mealor, and J. Magagna. 2013. Characterizing Wyoming ranching operations: Natural resource goals, management practices and information sources. Natural Resources 4:45-54.

Knight, K.B., T.P. Toombs, and J.D. Derner. 2011. Crossfencing on private U.S. rangelands: Financial costs and producer risks. Rangelands 33(2):41-44.

Lyons, R.K., and J.W. Stuth. 1992. Fecal NIRS equations for predicting diet quality of free-ranging cattle. Journal of Range Management 45:238-244.

Lyons, R.K., J.W. Stuth, and J.P. Angerer. 1995. Fecal NIRS equation field validation. Journal of Range Management 48:380-382.

Roche, L.M., B.B. Cutts, J.D. Derner, M.N. Lubell, and K.W. Tate. 2015a. On-ranch grazing strategies: Context for the rotational grazing dilemma. Rangeland Ecology and Management 68:248-256.

Roche, L.M., T.K. Schohr, J.D. Derner, M.N. Lubell, B.B. Cutts, E. Kachergis, V.T. Eviner, and K.W. Tate. 2015b. Sustaining working rangelands: Insights from rancher decision making. Rangeland Ecology and Management 68(5):383-389.

Rolfe, J.W., A.E. Larard, B.H. English, E.S. Hegarty, T.B. McGrath, N.R. Gobius, J. De Faveri, J.R. Srhoj, M.J. Digby, and R.J. Musgrove. 2016. Rangeland profitability in the northern Gulf region of Queensland: Understanding beef business complexity and the subsequent impact on land resource management and environmental outcomes. The Rangeland Journal 38:261-272

Rouquette Jr., F.M. 2017. Invited review: Management strategies for intensive, sustainable cow-calf production systems in the southeastern United States: Bermudagrass pastures overseeded with cool-season annual grasses and legumes. The Professional Animal Scientist 33(3):297-309.

Teague, W.R., P.B. DeLaune, and S.L. Dowhower. 2019a. Impacts of over-seeding bermudagrass pasture with multi-species cover crops on soil water availability, microbiology, and nutrient status in North Texas. Agriculture, Ecosystems and Environment 273:117-129.

Teague, W.R., S.L. Dowhower, S.A. Baker, N. Haile, P.B. DeLaune, and D.M. Conover. 2011. Grazing management impacts on vegetation, soil biota and soil chemical, physical and hydrological properties in tall grass prairie. Agriculture, Ecosystems and Environment 141:310-322.

Teague, W.R., and U.P. Kreuter. 2020. Managing grazing to restore soil health, ecosystem function and ecosystem services. Frontiers in Sustainable Food Systems 4:534187. https://doi.org/10.3389/fsufs.2020.534187.
Teague, W.R., U.P. Kreuter, W.E Grant., H. Diaz-Solis, and M.M. Kothmann. 2019b. Economic implications of maintaining rangeland ecosystem health in a semi-arid savanna. Ecological Economics 68:1417-1429.

Teague, W.R., F. Provenza, U.P. Kreuter, T. Steffens, and M. Barnes. 2013. Multi-paddock grazing on rangelands: Why the perceptual dichotomy between research results and rancher experience? Journal of Environmental Management 128:699-717.

Toombs, T.P., J.D. Derner, D.J. Augustine, B. Krueger, and S. Gallagher. 2010. Managing for biodiversity and livestock: A scale-dependent approach for promoting vegetation heterogeneity in western Great Plains grasslands. Society for Range Management 32(3):10-15.

USDA NRCS (Natural Resources Conservation Service). 2003. National Range and Pasture Handbook. 190-VI-NRPH, rev. 1. Washington DC: Grazing Lands Technology Institute.

USDA NRCS. 2013. National and State Resource Concerns and Planning Criteria (Updated 10/1/2013). Washington, DC: USDA NRCS.

Walker, J.W., R.K. Heitschmidt, E.A. De Moraes, M.M. Kothmann, and S.L. Dowhower. 1989. Quality and botanical composition of cattle diets under rotational and continuous grazing treatments. Journal of Range Management 42(3):239-242.

Wilmer, H., D.J. Augustine, J.D. Derner, M.E. FernándezGiménez, D.D. Briske, L.M. Roche, K.W.Tate, and K.E. Miller. 2018a. Diverse management strategies produce similar ecological outcomes on ranches in Western Great Plains: Social-ecological assessment. Rangeland Ecology and Management 71:626-636.

Wilmer, H., J.D. Derner, M.E. Fernández-Giménez, D.D. Briske, D.J. Augustine, L.M. Porensky, and the CARM Stakeholder Group. 2018b. Collaborative adaptive rangeland management fosters management-science partnerships. Rangeland Ecology and Management 71:646-657.

Windh, J.L., J.P. Ritten, J.D. Derner, S.I. Paisley, and B.P. Lee. 2019. Economic cost analysis of continuous-season-long versus rotational grazing systems. Western Economics Forum 17:62-72. 